\title{
LXI. New outlines of chemical philosophy
}

\section{Ez. Walker Esq.}

To cite this article: Ez. Walker Esq. (1815) LXI. New outlines of chemical philosophy, Philosophical Magazine Series 1, 46:211, 327-330, DOI: 10.1080/14786441508638553

To link to this article: http://dx.doi.org/10.1080/14786441508638553

曲 Published online: 27 Jul 2009.

Submit your article to this journal

III Article views: 2

Q View related articles $₫$ 
GH and IK parallel to AB. Make GH equal to $g h$, and IK to $i k$, and through the points $I, \Lambda, G$ and $K, B, H$, draw by eye the curved lines CIAGD and CKBIID, which will be the shape of the required gore. In the diagrain $I$ have divided FAE and DC into only four parts, for the sake of clearness: in practice, however, it is necessary to make use of eighteen or twenty divisions. 'This method is equally applicable to any shape which may be adopted, au advantage of which no other construction is possessed.

\section{New Oullines of Chemical Philosophy.} By Ez. Walker, Esq. of Lynn, Norfolk.

[Contiuued from p. 211.]

\section{On the Leyden Phial.}

$\mathrm{T}$ HE various hypotheses which have been invented to account for the phanomena of the Leyden plial plainly evince that the subject stift remaius in some obseurity. Nor is this to be wondered at, when we reflect that the properties of the electrical elements are so little understood, that philosophers are divided in their opinions respecting them. Franklin, Epinus, Robison, and some others, have supposed thit all electrical effects are produced by one fluid only; whilst Du Faye, Symmer, Cigna, Eeles, \&c. maintain that there are two fiuids, which exist together in all bodies, shat they counteract cach other when united, and can be made evident to the senses, only by tleir separation.

Men are too apt to adopt the opinions of others without strict examination. But it is an axiom in philosophy, which ought always to be liept in mind, that " no position should be assumed as the basis of any reasoning whatever, except what has beey proved by incontestable facts."

\section{General Properties of Electricity.}

1. It has been demonstrated by an instument, which may be called the pendulum elcctrometer, described in a former paper*, that the inechanical forces of these elements which produce a spark are equal, moving through each other; but the spark so produced is not an element, but the effect of those inyisible elements which are brought into action by the motion of the machine. But no spark can be produced unless those eleurnts pass through some conducting medium.

2. The two electrical elepents exist wgether in all bodies; which may be called their natural state. 
3. T'wo bodies electrified with contrary elements attract each other strongly, although an electric plate be interposed between them.

4. Two bodies electrified with the same element repel each other, although a thin electric plate be interposed between them.

\section{Application of these Properties to the Explanation of the Leyden Phial.}

When a Leyden phial is receiving a charge, a succession of sparks passes between the ball of the prime conductor and the ball upon the top of the phial; whence it is evident, from what has been previously stated, that when one of the elements (thermogen for instance) is thrown into the phial from the prime conductor, the other element (photogen) is attracted out of the phial by the former element, and by passing throngh the air in opposite directions they generate combustion. And as soon as the thermogen on the inside of the phial becomes sufficiently powerful to act through the two coatings and the glass contained between them, it repels the element of its own kind into the earth from the outside of the phial, and attracts the contrary element at the same time out of the earth; and as they pass through each other, they generate a spark at the bottom of the phial.

When all the photogen is drawn out of the phial, and an equal portion of thermogen is thrown in, the phial is fully charged; for then the outside of the phial is deprived of all its thermogen, and its place supplied with an equal portion of the, other element from the earth.

This is the theory of $\mathrm{Mr}$. Eeles, which appears to be well founded. Some objections, however, have lately been advanced against it by Mr. Donovan*, which ought not to be passed over in silence; for, if these objections cannot be answered by incontrovertible facts, the theory of electricity is still involved in obscurity?

Oljection 1. "If the contrary powers are situate on each surface of the charged phial, and if they strongly attract each othey through its substance, why do they not pass through it," since it has been proved that glass is permeable to each kind of electricity?

Answer. This objection will vanish when it is understood that the coating prevents the two elements from passing through the glass and combining. This conclusion must be admitted as a just one, since an uncoated phial cannot be charged; for these elements pass through glass as freely as light. More light will pass through thin glass than thick, and the same law seems to obtain in electricity.

* Phil, Mag. vol. xlir. p. 400. 
Oljection 2. It has been supposed that when one of the elements is passing from the inside of the phial towards the conductor, and the other from the conductor into the phial, "these two powers necessarily meet, and condense each other into the form of flame: they return to the natural state, and therefore do not exert any sensible action."

Answer. It has been proved by the pendulum electrometer that the two elements, after having passed through the card in opposite directions, still have power to throw off the two pendulums in a direction perpendicular to the card, so as to form an angle with each other of 70 degrees. Consequently the two elements exert a very sensible action on matter, after they have generated combustion, and before the return to their natural state.

The $3 \mathrm{~d}$ Ohjection is founded on the supposition that the two elements in the natural state have a strong attraction for each other.

"If the two electricities have so great an attraction, why did the power thrown in on one side overcome the attraction of the similar to the contrary power naturally co-existing on the other side? Why should not the natural combination remain unaltered, when it was maintained by a force equal to that which endeavoured to effect a separation of its component electricities?"

Answer. If the two elements of electricity have an attraction for each other in their natural state, it must be strongest where their quantities are greatest. Now the earth is the great repository of these elements, from whence all the electrical energy which is constantly acting in every part of the oconomy of vature is derived : consequently, according to this hypothesis, the attraction of these elements for each other must be inconceivably greater in the earth than in small quantities of matter.

How is it possible, then, that all the various compositions and decompositions in meteorology should take place, and that all the living functions of animals and vegetahles should be carried on, if a strong attraction existed in the natural state of these two elements?

From a great number of experiments which $I$ have made upon this subject, it evidently appears to be an invariable law of nature, that the slightest excitement of an electric is sufficient to attract the contrary element out of the earth.

The following experiment proves to a demonstration that the two elements of electricity, in their natural state, have no attraction for each other.

$A$ conductor $\mathrm{AB}$, consisting of a brass rod 12 inches long, having a ball of the same metal fixed to each end of it, was placed upon an insulating stand, and a jar electrometer placed 
at the end B. A glass tube 3-10ths of an inch in diameter being drawn once through a piece of silk held in the hand and placed at the distance of 12 inches from the end $A$ of the conductor $\mathrm{AB}$, the leaves of the electrometer diverged with positive electricity to an angle of $\mathbf{4 0}$ degrees. And the electrometer, being removed from the conductor before the tube began to lose its energy, remained permanently electrified. Hence the 3d Objection to the theory of the Leyden phial appears to be founded on a supposition which is erroneous.

$$
\text { Lynn, Nov. S, } 1815 .
$$

Ez. WALKER,

[To be continued.]

LXII. Statistical Account of ihe Quicksilver Mines of Idria in Illyria. By M. PAYsse, Superintendant of the Manufaeture of Mercurial Productions.

[Concluded from p. 312.]

$V_{\text {egetation is neither so active nor so early at Idria as at }}$ Laybach, and even Upper Laybach. The months of August and September are those in which vegetables seem to shoot out most luxuriantly.

A great number of rare and curious plants grow on the alps which surround Idria. The celebrated Scopoli has described them very minitely, and very few have eseaped him. Rye, barley and maize, succeed very badly around Idria.

The trees of which the forests are composed are various kinds of pines, yews, ash, \&c.

The leguminous plants are reared at great difficulty; besides, they are not juicy.

Fruits with kernels rarely ripen, and those gathered are tasteless and watery.

Apples and pears thrive a little better, and are fit to be eaten or used for cyder and perry.

The vine, which shoots up here vigorously, furnishes a grape which ripens but very rarely.

\section{Medical Constitution.}

Considered in a medical point of view, the climate of Idria is not insalubrious : those thiek and frequent fogs, which are the sources of many morbific affections to those who reside in the marshy plains of Laybach, do not prevail here.

The workmen are subject to certain fevers; phthisis is frequent: but the diseases which most generally prevail among the working class arise from a checked perspiration. It will be 